\title{
7
}

\section{Social Policy and Britain's 1929 Colonial Development Act}

\author{
Amanda Shriwise
}

\section{Introduction}

In 1929, Britain passed the Colonial Development Act (CDA), codifying its obligation to the development of the great estate with which it had been "entrusted". The CDA created a new financial instrument-the Colonial Development Fund (CDF)—and an accompanying advisory body - the Colonial Development Advisory Committee (CDAC) — that was responsible for making recommendations on how to allocate funds from the CDF to British colonies. While the CDA was not the only institutional mechanism through which Britain distributed aid to its colonies, it does represent the first time that colonial development assistance was centrally and systematically allocated across the British Empire.

\footnotetext{
A. Shriwise $(\bowtie)$

University of Bremen, Bremen, Germany

University of Kansas, Lawrence, KS, USA

e-mail: amanda.shriwise@uni-bremen.de 
Drawing on reports from the CDAC, parliamentary debates and secondary literature, this chapter examines social policy in a British colonial development context through the lens of the CDA from 1929 to 1940. It argues that while the CDF was a redistributive mechanism, it was far from progressive in both concept and implementation. As this chapter will demonstrate, the CDA aligned with and built upon previous notions of colonial development as economic development rather than subverting or transforming Britain's approach to colonial development policy in pursuit of social progress. As a result, social policy was part and parcel of fundamentally contradictory claims about welfare in the British Empire. Britain portrayed itself as a duty bound and philanthropic colonial power on the one hand while simultaneously pursuing a colonial development agenda that explicitly prioritised metropolitan economic gains over the welfare of local and indigenous populations on the other. Britain began to substantiate its commitment to social policy within its colonies only after the establishment of international standards through the League of Nations mandates system and when its image as a benevolent hegemon was threatened.

This chapter begins by briefly outlining key concepts for understanding social policy in a British colonial development context. Then, this chapter empirically examines British colonial development assistance from the CDF, focusing on the politics and objectives of the CDA, the CDA's implementation, the rationales and justifications that supported the approval of CDF funds spent in social policy areas, and the geographic and sectoral allocation of CDF funds for social policy in the colonies, before concluding.

\section{Social Policy in a British Colonial Development Context}

In the British Empire, social policy and welfare were integral to mechanisms of othering that underpinned colonialism itself. Colonies were established and perpetuated, in large part, through the annexation of territory and subsequent installation of extractive practices and racial hierarchies. As illustrated in seminal works by postcolonial scholars (e.g. 
Gramsci 1971; Said 1979), the latter was accomplished through the institutionalisation of implicitly self-referential, Eurocentric social frames, which not only excluded but also obscured, disempowered and even dehumanised alternative ways of being, living and seeing, further reinforcing the dominance of colonising powers. Social policy and welfare provision were no exception:

The basic ideology of the British Empire was built around spreading Victorian notions of betterment, improvement, progress, prosperity and civilization where there was perceived to be savagery, chaos, despotism, poverty, and slavery. In this sense, the British Empire was always a Victorian empire with an umbrella of broad welfare benefits at the heart of its selfpromoting ideology. (Lewis 2011, 26 - original emphasis)

Similar logics pervaded early conceptions of colonial development in the British Empire. Shortly after his appointment as Secretary of State for the Colonies, Joseph Chamberlain made a speech in the House of Commons on 22 August 1895 that signalled a shift from laissez-faire management of colonial development based on ad hoc offers of grant-inaid to colonies experiencing financial difficulties to one in which the state took a more active role in promoting economic development:

I regard many of our colonies as being in the condition of underdeveloped estates, and estates which can never be developed without Imperial assistance. It appears to me to be absurd to apply to savage countries the same rules which we apply to civilised portions of the United Kingdom ... I shall be prepared to consider very carefully ... and then ... confidently submit to the House, any case which may occur in which, by the judicious investment of British money, those estates which belong to the British Crown may be developed for the benefit of their population and for the benefit of the greater population which is outside. (House of Commons Debate, 1895, Volume 36, Columns 640-6).

Through Imperial investment in colonial transportation and communication infrastructure, Chamberlain argued that Britain could enable private investment in its colonies, resulting in both colonial economic development and metropolitan profits. 
Both Chamberlain's vision of colonial development as state-enabled, privately driven economic development and the notion of Britain having a duty and responsibility to develop the great estate with which it had been entrusted were only furthered after World War I (WWI), with greater attention to welfare. At the League of Nations, the notion of trusteeship became the dominant normative framework for the administration and development of mandated territories (Pedersen 2015). Frederick Lugard, former Governor-General of Nigeria and British Representative to the League of Nations Permanent Mandates Commission, describes this approach at length in The Dual Mandate in British Tropical Africa, referring to it as:

The principle that "the wellbeing and development of peoples not yet able to stand by themselves forms a sacred trust of civilization" ... The responsibility is one which the advantages of an inherited civilisation and a superior intellectual culture, no less than the physical superiority conferred by the monopoly of firearms, imposes upon the controlling Power. (Lugard 1922, 57)

During the early interwar period, ideas on how to further British colonial development began to circulate, with some suggesting that the British Government should secure loans raised by colonial administrations to spur economic development and with others calling for the extension of government grants, interest-free advances and subsidised loans, depending on the context. However, in the absence of both the right political window of opportunity and high-level support from the British Cabinet, none of these discussions resulted in the formulation of new policy or legislation to support colonial development across the British Empire in the early 1920s (Malmsten 1977). 


\section{Social Policy and the Colonial Development Fund, 1929-1940}

\subsection{The Formative Politics and Objectives of the Colonial Development Act, 1929}

Unemployment became an urgent political problem in Britain in the run up to the 1929 election, which took place several months before Black Tuesday. With considerable support in the Cabinet, an interdepartmental committee began reviewing proposals that could quickly reduce unemployment, and it was suggested that investment in colonial development could aid in this endeavour by catalysing Imperial trade and economic growth (Malmsten 1977). In the end, no formal action was taken on colonial development before May 1929, when the Conservatives lost their majority.

Less than two months after the election of the minority Labour government, the CDA became law on 26 July 1929. While it was widely known in political circles that investment in colonial development could make only a very limited contribution to alleviating unemployment in Britain (Morgan 1980), this framing positioned the CDA as one solution to the political problem of unemployment, which the new government had promised to take action upon during the election campaign (Constantine 1984, 191).

The CDA had two objectives: to aid and develop agriculture and industry in Britain's colonies; and to promote commerce with or industry in the United Kingdom (Colonial Development Act 1929, 1). The CDA applied to all British colonies and protectorates that were not selfgoverning, including the mandated territories Britain was responsible for administrating on behalf of the League of Nations (Colonial Development Act 1929, 3). ${ }^{1}$ Colonies in receipt of grant-in-aid from Britain were also eligible to apply; however, in practice, these colonies often had less

\footnotetext{
${ }^{1}$ In essence, the self-governing Dominions-India, Southern Rhodesia (present-day Zimbabwe), Malta, the Anglo-Egyptian Sudan (present-day Sudan and South Sudan), Iraq, and the New Hebrides (present-day Vanuatu) —were all excluded (Cmd. 3540, 7). However, both Newfoundland, which shifted its status from a Dominion to a crown colony in 1934, and Malta later received funds from the CDF (Cmd. 4916, 5).
} 
capacity to support development initiatives, making them less likely to benefit from the Act (Cmd. 6298, 9; Wicker 1958).

The CDA stipulated that its objectives were to be achieved through a number of means of economic development as well as through the promotion of public health, which presented the clearest link between the CDA and social policy in British colonies. One of the first debates with respect to the CDA on 24 February 1930 in the House of Commons suggests that public health was included, in part, because it provided a clear way to demonstrate support for the well-being of colonial inhabitants, which was a core element of trusteeship at the League of Nations and mandatory powers were wise to pay some homage (House of Commons Debate, 1930, Volume 235, Columns 1949-81). Furthermore, reducing the threat of infectious disease helped to protect international trade and colonial troops, administrations and settlers, as well as the supply of indigenous labour upon which colonial plantation owners and mining magnates depended. Moreover, improving public health through modern sanitation systems and Western medicine reinforced the image of colonialism as a civilising mission, which was doubly important given the history of European colonisers introducing infectious diseases that ravaged indigenous populations (Chakrabarti 2013). ${ }^{2}$

To support these means to colonial development, the CDA created the CDF, which received $£ 1$ million from Parliament each year. ${ }^{3}$ There is evidence to suggest that the figure of $£ 1$ million was based on estimates of what colonies could reasonably absorb over the course of one year (Wicker 1958, 175). The CDF was allowed to make grants or loans to British colonies that "may be applied by the Government to which they are made either directly or through any person or bodies of persons" as His Majesty's (HM) Treasury saw fit (Colonial Development Act 1929, 2). This clause effectively opened the door for colonial governments to channel CDA funds to private entities within their territories, whether

\footnotetext{
${ }^{2}$ The impact of infectious disease introduced by European colonisers on indigenous populations was particularly pronounced in the Americas, where "it is estimated that up to 90 per cent of the indigenous population in certain parts of the Americas were wiped out" (Chakrabarti 2013, 73).

${ }^{3}$ Between 1929 and $1939, £ 1$ million was, on average, the equivalent of approximately $£ 68.9$ million in 2020 .
} 
for-profit firms or not-for-profit entities, such as missions. Colonial governments were also allowed to use CDF funds to cover the interest on development loans raised independently by colonial governments for a period of up to ten years (Cmd. 3540, 21).

Parliament's annual $£ 1$ million contribution to the CDF came with two conditions: the observation of fair labour conditions (including both standard wage rates and no forced or child labour, defined as the employment of those under twelve years of age), which also aligned with standards set for mandatory powers at the League of Nations; and ensuring that colonies benefit from any profits derived off the back of CDF investments (Colonial Development Act 1929, 3). Finally, any CDF loan repayments would be paid into the Exchequer, not to the CDF specifically (Colonial Development Act 1929, 4).

The CDA also calls for the creation of what came to be known as the CDAC to make recommendations on the allocation of these funds throughout Britain's colonies. The committee was to be appointed by the Secretary of State for the Colonies subject to approval by HM Treasury (Colonial Development Act 1929, 4). The CDAC was not empowered to suggest development projects or initiatives within colonies nor did it have a comprehensive picture of the developmental needs of each colony; instead, the Committee members evaluated requests for funding in line with the Committee's mandate to stimulate economic development in the colonies in a way that increased trade and fostered job creation in the metropole.

\subsection{Implementation of the Colonial Development Act, 1929}

As indicated in its first report, the CDAC derived its mandate directly from the CDA's twin objectives of promoting economic development in Britain's colonies and promoting commerce and job creation in the United Kingdom. The Colonial Office (CO) took a number of executive actions to ensure that the Secretary of State for the Colonies was in compliance with the conditions of the legislation. In addition to ensuring standard wages and the absence of forced and child labour, Sydney Webb, 
then Secretary of State for the Colonies, suggested that colonial governors consider ways to acquire a share of any increase in land value that resulted from investments made by the CDF. Furthermore, in all cases where funds from the CDF were meant to be channelled through a company, Webb called for the consideration of: "(i) whether, and if so to what extent, the Government should participate, either as a shareholder or otherwise, in any profits of the Company directly attributable to that assistance, and (ii) whether it should assume a share of responsibility for the direction of the Company" (Cmd. 3540, 10). The CO also clarified that projects funded by the CDF should endeavour to place orders for imported material and equipment in the United Kingdom - a criticised, but ongoing practice across a number of countries today referred to as "tied aid" - and that colonial governments should submit bi-annual progress reports to the CDAC on the implementation status of CDFfunded projects, including reporting on associated labour conditions (Cmd. 3540, 11).

At its first meeting on 1 August 1929, the CDAC clarified the institutional mechanism supporting the allocation of funds from the CDF

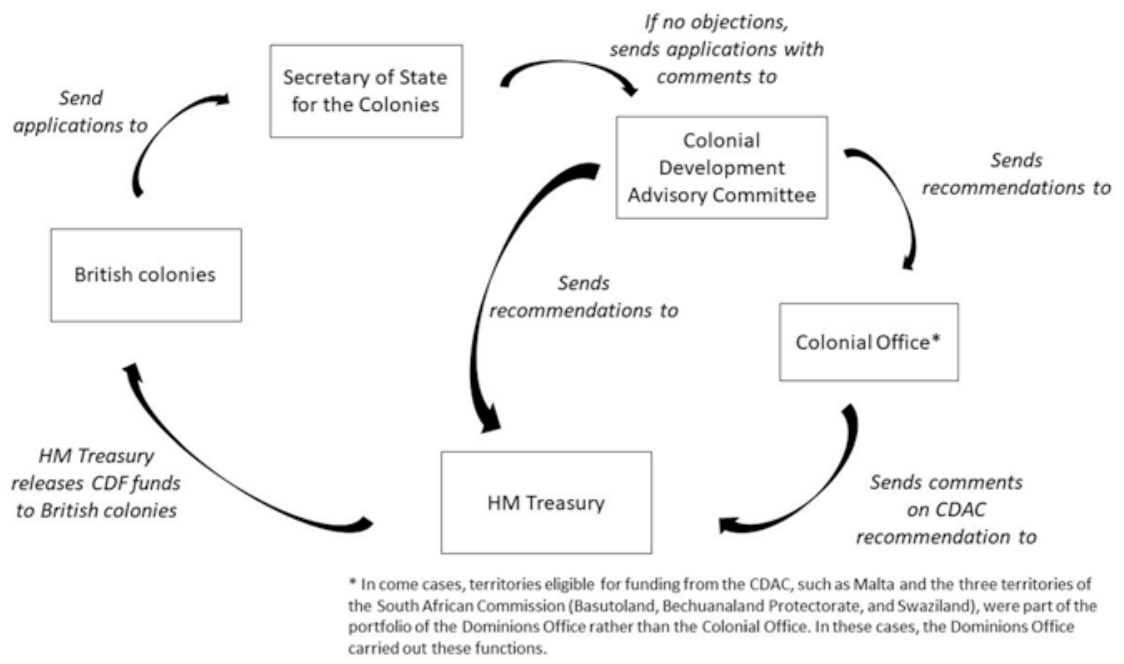

Fig. 7.1 Institutional mechanism supporting the allocation of funds from the CDF 
(Fig. 7.1), provided input on guidance for colonial administrations on how to apply to the Fund, which was sent in a circular dispatch on 10 August 1929, and recommended that this dispatch was preceded by a circular telegram informing colonial administrations of the passage of the CDA, which was sent on 7 August 1929 (Cmd. 3540). In total, the CDAC held fifteen meetings during its first seven months of operation alone, not least because the first $£ 1$ million issued to the CDF needed to be allocated before the end of the fiscal year; otherwise, these funds would revert to the Exchequer, in addition to raising more fundamental questions about the viability of implementing colonial development projects (Cmd. 3540, 23).

The CDAC proved to be a functional and politically stable entity. From its first meeting in August 1929 to the end date of its eleventh and final report on 17 July 1940, the Committee met at least 125 times, or approximately once per month. During the formulation of the CDA, there was some debate over whether the CDAC should be chaired by government officials and comprised of individuals with business experience and representatives from colonies or whether it should be a more independent body without governmental representation. In the end, the Government's preference for a more independent committee that was less subject to ongoing disputes between the CO and HM Treasury but with business experience prevailed (Overseas Development Institute 1964, 16). Over time, the CDAC was comprised of individuals who together had extensive experience in the areas of finance, trade union organisation, chartered accounting, engineering and public works, and colonial governance, as well as board members of several influential firms, including Cable and Wireless and De Beers Consolidated Mines and chairmen of several chambers of commerce; while some of the committee members were sympathetic to the provision of social services, especially medical and health research, none of the committee members had extensive expertise in these areas (for names of CDAC members, please see Cmd. 3540, Cmd. 3876, Cmd. 4079, Cmd. 4316, Cmd. 4634, Cmd. 4916, Cmd. 5202, Cmd. 5537, Cmd. 5789, Cmd. 6062, and Cmd. 6298). 


\subsection{The Allocation of Financial Support from the CDF}

The CDAC's first meeting report specifies a number of criteria used to decide whether or not projects should receive support from the CDF in line with its legislative mandate (Cmd. 3540). In particular, the CDAC was looking for schemes that were well placed to have a positive multiplier effect (Abbott 1971), whereby colonial economic development projects also stimulated the need for items manufactured in the United Kingdom, thereby fostering job creation in the metropole while improving the condition of the colonies. However, the CDAC also required that proposed schemes were economically sound, that they could not be undertaken by colonial governments with their own resources and that colonial governments could take on any maintenance or recurring expenditure that resulted from CDF investments. The CDAC and HM Treasury also occasionally placed conditions on colonial governments in line with the receipt of CDF funds, and, in many cases, projects were jointly financed with colonial governments and other entities.

Additionally, the CDAC made clear that they were not keen to fund anything resembling normal, recurrent expenditure in the colonies in line with the long-standing view that colonial governments should be financially self-sufficient entities. While this principle proved detrimental to funding education expenses through the CDF, as stated explicitly in the CDAC's first annual report (Cmd. 3540, 17), funding for health fared much better given its explicit inclusion as a means through which to support colonial development in the Act itself. Health was conceptualised largely as preventing negative multiplier effects and funding justifications focused in particular on preventing disease and improving hygiene and sanitary conditions within the colonies, with occasional support for expanding health infrastructure, such as hospitals and dispensaries. Over the lifetime of the Committee, the CDAC allocated 16 percent of the $\mathrm{CDF}$ to public health, second only to the 30 percent allocated to transportation and communications (Cmd. 6298, 11).

While the CDAC explicitly set out to avoid providing temporary assistance during times of distress without the prospect of a permanent economic benefit (Cmd. 3540, 16), welfare ultimately proved difficult for 
the Committee to ignore. In particular, failures in the sugar market in the West Indies resulted in high levels of distress and instability, and eventually, a Royal Commission was tasked with examining both economic and social conditions in the region. The Commission released their report in 1940, finding that:

There is a pressing need for large expenditure on social services and development which not even the least poor of the West Indian Colonies can hope to undertake from their own resources. (as quoted in Wicker 1958, 180-Wicker's emphasis)

The Commission's findings played a substantial role in the reformulation of the CDA as the Colonial Development and Welfare Act, 1940. As suggested in its short title, the Act placed a greater emphasis on welfare in colonies, including the ability to finance education, in addition to increasing the funding ceiling for colonial development fivefold to $£ 5$ million a year and the forgiveness of any outstanding debt colonial governments had to the CDF. However, emphasis on welfare and implementation of the new approach was overshadowed by the onset of World War II, and Britain spent less than $£ 6$ million in total on colonial development and welfare between 1940 and 1945 (Wicker 1958, 176).

Furthermore, as argued by Malmsten (1977), high-level support for including welfare in colonial development efforts grew not only out of concerns related to poverty or social unrest-which had been persistent and ongoing throughout the British Empire-but out of the need to protect and preserve Britain's image amid its hegemonic decline. In 1938, Malcom MacDonald, then Secretary of State for the Colonies, told a CO colonial development committee that:

In the future, criticism of Great Britain would be directed more and more against her management of the Colonial Empire, and it was essential to provide as little basis as possible for such criticism. It was an essential part of her defence policy that her reputation as a Colonial power should be unassailable. (Malmsten 1977, D1283)

In a fashion somewhat analogous to the initial passage of the CDA (Malmsten 1977, D1286), MacDonald successfully made the case to 
expand the Act's scope and financing in 1940 based not on the social needs of colonial inhabitants but on the grounds that colonial development and welfare were in Britain's self-interest-and this remains the most robust line of argumentation for development and foreign assistance to date.

\section{Conclusion}

Social policy in British colonies was representative of contradictory tensions underpinning Britain's justification for its position as a hegemonic colonial power. British colonial development policy was originally conceived to promote colonial economic development and metropolitan profits, with minimal concern for the welfare of local and indigenous populations. However, after WWI, emphasis on trusteeship and the welfare of indigenous populations in the League of Nations mandates system did lead to greater funding for public health in British colonies, which emerged as the second largest area of investment for the CDF after transportation and communication. After market failures and subsequent unrest in the West Indies, further investment in colonial development and welfare after 1940 was supported largely to preserve Britain's image as a philanthropic and benevolent hegemon amid its decline. While CDF investments in health in British colonies were likely far too small to result in substantial welfare gains for local and indigenous populations, these findings suggest that international visibility through the mandates system did nudge colonial powers towards greater accountability and constrain their ability to side-line welfare concerns in pursuit of economic development and metropolitan profits. Ultimately, arguments emphasizing why the welfare of colonial inhabitants was central to Britain's self-interest were most successful in garnering metropolitan support for advancing social policy in Britain's colonies, however minimal these gains were in practice.

Acknowledgement My thanks to Jakob Kaiser for his research assistance on the background and experience of members of the Colonial Development Advisory Committee. 


\section{References}

Abbott, George C. 1971. A Re-Examination of the 1929 Colonial Development Act. The Economic History Review 24 (1): 68-81.

Chakrabarti, Pratik. 2013. Medicine and Empire, 1600-1960. Basingstoke: Palgrave Macmillan.

Constantine, Stephen. 1984. The Making of British Colonial Development Policy, 1914-1940. London: Frank Cass and Company Ltd.

Gramsci, Antonio. 1971. Selections from the Prison Notebooks of Antonio Gramsci. London: Lawrence and Wishart.

Lewis, Joanna. 2011. The British Empire and World History: Welfare Imperialism and 'Soft' Power in the Rise and Fall of Colonial Rule. In Colonialism and Welfare: Social Policy and the British Imperial Legacy, ed. James Midgley and David Piachaud, 17-35. Cheltenham: Edward Elgar.

Lugard, Frederick John Dealtry. 1922. The Dual Mandate in British Tropical Africa. London: William Blackwood and Sons.

Malmsten, Neal R. 1977. British Government Policy toward Colonial Development, 1919-39. The Journal of Modern History 49 (2): D1249-D1287.

Morgan, David J. 1980. The Official History of Colonial Development. London: Macmillan.

Overseas Development Institute. 1964. British Aid-5, Colonial Development: A Factual Survey of the Origins and Histories of British Aid to Developing Countries. London: The Overseas Development Institute Ltd.

Pedersen, Susan. 2015. The Guardians: the League of Nations and the Crisis of Empire. Oxford: Oxford University Press.

Said, Edward. 1979. Orientalism. New York: Vintage Books.

Wicker, Elmus R. 1958. Colonial Development and Welfare, 1929-1957: The

Evolution of a Policy. Social and Economic Studies 7 (4): 170-192.

\section{Legislation}

The United Kingdom of Great Britain and Northern Ireland. 1929. Colonial Development Act. 20 Geo. 5 Ch. 5. London, July 26. 


\section{Parliamentary Debates}

House of Commons of the United Kingdom. 1895. House of Commons Debate. Volume 36, Columns 640-6. London, August 22.

1930. House of Commons Debate. Volume 235, Columns 1949-81. London, February 24.

\section{Parliamentary Papers}

Cmd. 3540-First Interim Report of the Colonial Development Advisory Committee, Covering the Period. 1st August, 1929-28th February, 1930, London: HM Stationary Office.

Cmd. 3876-Colonial Development Advisory Committee, Second Interim Report Covering the Period. 1st March, 1930-31st March, 1931, London: HM Stationary Office.

Cmd. 4079-Colonial Development Advisory Committee, Third Interim Report Covering the Period. 1st April, 1931-31st March, 1932, London: HM Stationary Office.

Cmd. 4316-Colonial Development Advisory Committee, Fourth Interim Report Covering the Period. 1st April, 1932-31st March, 1933, London: HM Stationary Office.

Cmd. 4634-Colonial Development Advisory Committee, Fifth Annual Report Covering the Period. 1st April, 1933-31st March, 1934, London: HM Stationary Office.

Cmd. 4916-Colonial Development Advisory Committee, Sixth Annual Report Covering the Period. 1st April, 1934-31st March, 1935, London: HM Stationary Office.

Cmd. 5202-Colonial Development Advisory Committee, Seventh Annual Report Covering the Period. 1st April, 1935-31st March, 1936, London: HM Stationary Office.

Cmd. 5537-Colonial Development Advisory Committee, Eighth Annual Report Covering the Period. 1st April, 1936-31st March, 1937, London: HM Stationary Office.

Cmd. 5789-Colonial Development Advisory Committee, Ninth Annual Report Covering the Period. 1st April 1937-31st March 1938, London: HM Stationary Office.

Cmd. 6062-Colonial Development Advisory Committee, Tenth Annual Report Covering the Period. 1st April 1938-31st March 1939, Presented by the 
Secretary of State for the Colonies to Parliament by Command of His Majesty, July 1939, London: HM Stationary Office.

Cmd. 6298-Colonial Development Advisory Committee, Eleventh and Final Report Covering the Period. 1st April, 1939-17th July, 1940, Presented by the Secretary of State for the Colonies to Parliament by Command of His Majesty, July 1941, London: HM Stationary Office.

Open Access This chapter is licensed under the terms of the Creative Commons Attribution 4.0 International License (http://creativecommons.org/licenses/ by/4.0/), which permits use, sharing, adaptation, distribution and reproduction in any medium or format, as long as you give appropriate credit to the original author(s) and the source, provide a link to the Creative Commons licence and indicate if changes were made.

The images or other third party material in this chapter are included in the chapter's Creative Commons licence, unless indicated otherwise in a credit line to the material. If material is not included in the chapter's Creative Commons licence and your intended use is not permitted by statutory regulation or exceeds the permitted use, you will need to obtain permission directly from the copyright holder.

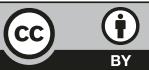

